\title{
The Triumph of Maori Entrepreneurs or Diverse
} Economies?

\author{
Maria Bargh \\ Victoria University of Wellington
}

aboriginal policy studies Vol. 1, no. 3, 2011, pp. 53-69

This article can be found at:

http://ejournals.library.ualberta.ca/index.php/aps/article/view/12560

ISSN: $1923-3299$

Article DOI: http://dx.doi.org/10.5663/aps.vli3.12560

aboriginal policy studies is an online, peer-reviewed and multidisciplinary journal that publishes original, scholarly, and policy-relevant research on issues relevant to Métis, nonstatus Indians and urban Aboriginal people in Canada. For more information, please contact us at apsjournal@ualberta.ca or visit our website at www.ualberta.ca/nativestudies/ aps/ or http://ejournals.library.ualberta.ca/index.php/aps/. 


\title{
The Triumph of Maori Entrepreneurs or Diverse Economies?
}

\author{
Maria Bargh \\ Victoria University of Wellington
}

\begin{abstract}
Tuaropaki Power Company is the first Maori geothermal power company-a successful power company that built its own power station and sells electricity to the national grid in Aotearoa, New Zealand. After wresting their lands back from government control, the people of the Tuaropaki Trust are now an inspiration for other tribes when it comes to charting an independent direction. Tuaropaki Power Company is not only celebrated for charting an independent direction, but has also been held up as evidence that an independent direction for tribes lies in using corporate structures and a particular type of entrepreneurship. But is that all that the Tuaropaki Power Company represents? I argue that using a diverse economies framework allows for broader definitions of companies like Tuaropak, and for Maorieconomies more generally, and provides a richer picture of what is taking place.
\end{abstract}

\section{The Triumph of Maori Entrepreneurs or Diverse Economies?}

Tuaropaki Power Company is the first Maori geothermal power company-a successful power company that built its own power station and sells electricity to the national grid in Aotearoa, New Zealand. After wresting their lands back from government control, the people of Tuaropaki Trust are now an inspiration for other tribes when it comes to charting an independent direction. Tuaropaki Power Company is not only celebrated for charting that independent direction, but has also been held up as evidence that an independent direction for tribes lies in using corporate structures and a particular type of entrepreneurship. But is that all that the Tuaropaki Power Company represents?

This article began with my desire to write about what I saw as an exciting activity: a Maori geothermal power company. This desire was followed quickly by two concerns. My first concern was that proponents of entrepreneurialism were taking credit for Maori involvement in energy production, and more generally in other economic activities, as evidence of the triumph of entrepreneurialism and of a "business mode of developing" over, or in spite of the presence of, traditional Maori institutions.

By entrepreneurialism I mean the theories based on the idea that there are "members of society who are 'entrepreneurial individuals"' (Shane 2003), with a number of core attributes such as alertness (Keelan and Woods 2006, 2). My second concern revolved around how to write enthusiastically about a Maori geothermal company-which, on the face of it, may appear to simply be a capitalist business activity-without lapsing into naïve optimism and/or inadvertently becoming an apologist for capitalist activity.

aboriginal policy studies, Vol. 1, no. 3, 2011

ISSN: 1923-3299 
In this article I attempt to explore the ways that different critiques-in this case, of Maori economic activities-create different institutional politics. First, I interrogate some of the dominant claims and enthusiasm about Maori involvement in corporate activities. I examine the ways in which developmental views of humanity, which contain assumptions that all peoples can be ranked according to their levels of development, are particularly interrelated with the discourse around Maori as entrepreneurs. I suggest that, while a number of strands of these developmental views of humanity presume that Maori developmental "deficiencies" can be remedied by embracing "modern" (Western) institutions, this presents a far too simplistic view.

In the second part of the article I examine whether simplistic assumptions made about Maori may be ameliorated by thinking in terms of a diverse economy and deploying different theoretical tactics. If so, it may be possible to dislodge developmental views of humanity and accompanying notions of Maori institutions as allegedly "of the past" and as allegedly less "advanced." I argue that the diverse economies framework is one that has the potential to allow for broader definitions of Maori economies and to provide a richer picture of what is taking place. ${ }^{1}$

\section{Hamstrung by the Past?}

Critiques of Maori political and economic institutions that focus on Maori culture and history as "holding Maori back" often recommend corporate structures as a way "forward." In his article "The Past is Another Culture," Barry Hindess (2007) examines these kinds of notions of alleged primitiveness and civilization alongside the idea of a universal history where all people are ranked on a continuum according to institutional, intellectual, and moral development. At one end of the continuum, peoples are seen as "undeveloped" (which often gets conflated with being non-Western), while at the other end peoples are understood as fully developed (which is often equated with being Western and living in a liberal democracy).

A number of Indigenous scholars have contested developmental understandings of humanity and the role that many academic disciplines have played in perpetuating such notions (Smith 1999; Escobar 1997; LaDuke 2005; Shiva 2000). Linda Tuhiwai Smith argues that it is through "disciplines that the indigenous world has been represented to the West and it is through these disciplines that indigenous peoples often research for the fragments of ourselves which were taken, catalogued, studied and stored" (1999, 58-59). Smith argues that dominant in the field of knowledge is "research "through imperial eyes" (56), which, she argues, "describes an approach which assumes that Western ideas about the most fundamental things are the only ideas possible to hold, certainly the only rational ideas, and the only ideas which make sense of the world, of reality, or social life and of human beings" (56). An even wider literature of post-colonial writing, largely stemming from English and literary studies, has involved scholars writing back to the colonizer and challenging colonial assumptions and practices, including the ideas that some peoples are more advanced than others (Said 1978; Ashcroft, Griffiths, Tiffin 1989; Young 2001).

While much of the literature that suggests that Maori people and traditions are less modern/Western, and therefore less civilized, couches their critiques in opaque ways (Rata 
2000), a paper by Frédéric Sautet and published by the New Zealand Business Roundtable provides a usefully clear account. Sautet openly stresses the failings of Maori institutions and their need to become "modern" $(2008,29)$. He argues that traditional tribal structures are clearly no longer appropriate models to govern Maori as there is a fundamental incompatibility between Maori culture and modernity. Sautet concludes his paper by saying that,

Maori development is based on private enterprise and the unleashing of entrepreneurial talents... traditional Maori institutions must blend within the modern structure of the market system... This can be done while preserving some aspects of the cultural heritage of the past...but not all aspects, and this is the lesson of the modern world (29).

Sautet is engaged in this particular paper in a counter-factual, which encourages him to draw a number of conclusions that might not easily be reconciled with Maori history.

\section{Maori Entrepreneurs}

As part of what some have described as a "Maori renaissance" (Henry 2007), there is a growing literature on a Maori economic identity (Hui Taumata 2005; Anderson, Dana, and Dana 2006; Whitehead and Annesley 2005; O'Sullivan and Dana 2008) and, specifically, on a Maori entrepreneurial identity (Keelan and Woods 2006; Warriner 2009; Tapsell and Woods 2008; Te Puni Kokiri 2007). There are a number of issues that this emerging literature is responding to and bringing together. In the work of many of these scholars, there is an explanation of the link between the undervaluing of Maori activities and experiences in the early colonial period in New Zealand and the need to highlight and emphasize Maori economic identities and successes. In some senses, this is similar to my arguments here in that I am seeking to expand the conversation about what counts as part of the economy. Where these conversations perhaps diverge from my own is when "entrepreneurialism" is defined as being lodged within a capitalist understanding of economy, with assumptions ensuing about people as being "rational self-maximizing individuals" (Bargh 2007, 8) and a privileging of commercialization and economic growth (see Dana and Anderson 2007). I will return to this point shortly.

One of the ways that theorists of Maori entrepreneurship have sought to validate Maori economic activities is by arguing that there is a link between Maori traditions and entrepreneurship and, indeed, that entrepreneurship has always been part of Maori society (Pihama and Pinehira 2005). These perspectives appear to seek to locate the Maori pursuit of entrepreneurship in business by showing its compatibility with Maori traditional stories. It is not the traditional institutions and stories in and of themselves that are celebrated on their own terms but, rather, their apparent similarity to entrepreneurship and "free" market values. Arguably, Maori traditional stories could still therefore be misunderstood as features "of the past," which have the potential to be improved if reconciled with the allegedly more sophisticated institutions and moral attributes of the "present"/"modern"/ Western world.

Teorongonui Josie Keelan and Christine Woods have developed a model of Maori entrepreneurship based on the metaphor of the "Mauipreneur" (Keelan and Woods 
2006, 17). Maui is a well-known male character of Maori stories/folklore who, during his adventures, often takes risks, creates mischief, and achieves his results, like taming the sun (Reed 2004). Keelan and Woods argue that Maui is an "exemplar of entrepreneurial behaviour" (Keelan and Woods 2006, 3). Keelan and Woods $(2006,6)$ highlight particular behaviours and principles of Maui such as Mauri, (life force or energy), Mana (authority), Ata (planning), and Arataki (leadership), which they argue are consistent with their understandings of an entrepreneur: "being alert to opportunity and taking action to make things happen" (17).

One of the outlined aims of the Keelan and Woods article is to produce a teaching and learning tool that can encourage young Maori to become more entrepreneurial; this is the reason why Keelan and Woods argue that this metaphor is "a 'Maori friendly' way of understanding entrepreneurship and acknowledging this as something that has always existed within Maori society" $(2006,14)$. By suggesting to young Maori that their traditional cultural values may already be akin to those being taught (and valued) by the dominant culture in New Zealand, they aim to make the learning process easier.

Te Puni Kokiri (the Ministry of Maori Development) has also contributed to connecting some of the ideas about Maori development with entrepreneurship. In a 2007 report, For Maori Future-makers, Maori are encouraged to join and foster the "innovation economy" as the "way forward" (37). The report argues that "Maori economic performance will be enhanced by promoting higher levels of entrepreneurship" (37).

Leonie Pihama and Mera Pinehira (2005) have explored the difficulties and potential of an entrepreneurship discourse as part of a search by Te Puni Kokiri to represent Maori and Maori development more positively. Pihama and Pinehira ultimately conclude their research by suggesting, much as Keelan and Woods do, that "entrepreneurship" has always been a feature of Maori society. This conclusion appears somewhat problematic, however, given that the kinds of activities the authors ascribe to entrepreneurship could also largely be categorised as innovative, but without necessarily containing the individualistic and capitalist elements often included in dominant definitions of entrepreneurship (Samuelson and Nordhaus 1995, 368; Shane, 2003; Bannock, Baxter, and Davis 1998).

Ella Henry defines what she calls "Kaupapa Maori entrepreneurship" as "social entrepreneurship, in that it is entrepreneurial activity, but it is underpinned by social objectives to improve wealth and well-being for the community, rather than just the individual" $(2007,542)$. She adds, however, that, "entrepreneurs operate in an environment of risk, and require the flexibility to capitalize on opportunities and develop new innovations, without being hamstrung by community decision-making processes and shared ownership of resources" (543).

As part of the discourse of this kind of Maori entrepreneurialism (where the notion of entrepreneurialism is individualistic and capitalist but conducted by Maori with social objectives), Maori businesses are often highlighted as shining examples of Maori entrepreneurialism in action. These Maori businesses are portrayed as evidence that Maori entrepreneurialism works for Maori, that it produces the benefits of "modernizing" Westernizing for Maori, and will translate into benefits for the wider Maori community (see Te Puni Kokiri 2005). 
It is at this point that the discourse of Maori entrepreneurialism comes close to echoing a discourse of "diverse economies" (Gibson-Graham 2006). Both claim to move away from rigid statements or positions about Maori culture; both seek to highlight the grey areas, the overlap, the diversity of Maori businesses, with their elements of market values and culture as well as dynamic Maori values and culture. Where they diverge is that dominant discourses of entrepreneurialism (Shane 2003) continue to be underpinned by developmental understandings of humanity. Maori institutions and people are, therefore, implicitly understood as still being at a less advanced position on the continuum-a position which could be modified by embracing more "modern (Western) institutions" and the attributes of an entrepreneur. In addition, entrepreneurial discourse is centred on promoting the success and well-being of the rational and self-maximizing individual first, albeit with potential "spin-offs" for others locally, nationally, and internationally from this success and well-being (Warriner 2009). And, finally, the entrepreneurial discourse continues to privilege commercialization and economic growth as the primary means by which Maori should enhance their well-being.

Some Maori have pointed to the need for broader notions of well-being for communities that take into account communal land ownership and decision-making (Durie 1998; Smith 2007; Bargh 2002). In a similar way, the diverse economies literature focuses on the well-being of whole communities first and the equitable and appropriate distribution of production, surplus, and enterprises amongst and within these communities (GibsonGraham 2006; Cameron and Gibson 2008). For Maori, one of the points of difference from a diverse economies approach may be that the highest priority is the well-being of particular peoples that are genealogically connected, such as hapu (sub-tribes), iwi (tribes), or other locally located Maori communities. In addition, a concern for how land is utilised and the environmental consequences may also be of concern, alongside and entangled with other competing compromises and realities (Lewis and Underhill-Sem 2008).

\section{Methods and Methodology}

Those who view putting Maori on the "correct" path to modernize (become more Western) and prosper by becoming entrepreneurs and acquiring institutions compatible with "the market" and, indeed, often the critiques of these views (by "Leftists") might benefit from taking a broader view. Mauipreneurs are neither simply capitalist, nor simply apologists for corporate activity. They may not be strictly anti-capitalists either. But what are the best ways to take a broader view? Kaupapa Maori theory has become a popular theory for Maori to use when working on Maori topics-might it be appropriate for the considerations here? Although I do not want to digress too far from the issue at hand, the question of whether all research with Maori and by Maori must necessarily use Kaupapa Maori theory is a question which deserves some attention.

Kaupapa Maori theory has emerged largely in response to colonization and to Maori people and Maori knowledge being exploited by non-Maori researchers with little or no connection to the groups they researched (Mahuika 2010). Much of Kaupapa Maori theory has come from the discipline of education and provides a critique of colonial methods of research and knowledge and outlines methods for conducting research that is critical 
and appropriate (Smith 1999; Irwin 1994; Cram 2001). Kaupapa Maori has an avowedly critical resistance stance. Leonie Pihama argues that "Kaupapa Maori theory must be about challenging injustice, revealing inequalities, seeking transformation" (2001, 110). Similarly, Jessica Hutchings argues that "Kaupapa Maori is inherently about tino rangatiratanga" (2002, 57). There is often a focus in Kaupapa Maori research on establishing the most appropriate ways to conduct interviews, the dynamics between researcher and the "researched," the interpretation of data and recording, and documenting accounts from people (Kennedy and Cram 2010; Smith 1999; Hutchings 2002).

Given the focus of Kaupapa Maori theory on interviews, I did not consider it to be the most useful way of delving into a conversation on diverse economies. While research involving participants can provide rich details of a case, it is only one of many ways to collect and analyze information. Textual or literary analyses and studies also provide insights into the discourse surrounding various topics and projects (Te Punga Somerville 2011).

In addition, while research that is directed by and useful for specific Maori groups "being researched" is needed, at the same moment it is also useful to consider where conversations may exist that may not be of interest to those being researched but that may provide useful insights for others, or that might produce long-term beneficial theoretical consequences. The consequences of a radically unrestrained "academic freedom," which objectifies Indigenous peoples, does little or nothing for them, and creates an "expert" out of the non-Indigenous or colonial researcher, have been well articulated (Smith 1999). But to what extent should Indigenous researchers restrict their curiosity simply to those topics directed by their communities, to people they know, and/or to those intellectuals that are Indigenous? At a conference specifically on Kaupapa Maori theory, Alice Te Punga Somerville (2011) asks what Kaupapa Maori enables and, importantly, "What does it shut down?" (7). For her work, which is largely based in literary studies, Te Punga Somerville argues that "sometimes it feels like the phrase 'Kaupapa Maori' has become a diminishing rather than space-opening thing" (7). Te Punga Somerville recounts what she found to be a disturbing conversation with "an enthusiastic and smart young wahine [woman]" who told her that "because she is using Kaupapa Maori research methodologies for her $\mathrm{PhD}$ she is only reading scholarly work by Maori writers" (Te Punga Somerville 2011, 7). What are the implications of such a direction? Anaru Eketone (2008) has also questioned how Kaupapa Maori theory is able to create space when the theory itself is based on Western academic ideas and yet positions itself purposefully in direct opposition to Western approaches. Eketone argues that a productive way forward for Kaupapa Maori theory is to focus more on a general concern "to develop and advance as Māori using our own knowledge, values, and processes" $(2008,10)$.

The questions raised by Te Punga Somerville and Eketone point to an emerging conversation within Maori Studies about the need to think in different ways, to unlink Indigenous identity from colonization, with its accompanying assumptions about a perpetual decolonization struggle. In his article "A Genealogy of Indigenous Resistance," Brendan Hokowhitu (2010) suggests that continuing to position Indigenous identity in a binary with colonization and, by extension, presenting Indigenous identity as coupled with a perpetual struggle for de-colonization is problematic and limiting. He also suggests that the "assertion of indigenous self-determination in constant referral to the colonizing other 
merely serves to re-establish the neo-imperial colonial power structures themselves" (210). A worthier project than that of decolonization, Hokowhitu argues, is one of "indigenous existentialism, including discussion surrounding the immediacy of indigenous culture and the stirring forms of cultural expression that occur at cultural borders" (215). While thinking outside the Indigenous peoples-colonization binary implies "fragmentation and uncertainty," Hokowhitu suggest this should be reframed as useful, in order to "enjoy the materiality of our situation, to live free of the consciousness of the will to power of another, to live free of occupation..." (223-24)

Given the purpose of my research to explore what a conversation that is not located within a critical or resistance stance might achieve, a strict observance of Kaupapa Maori appeared to present more limitations than openings in this instance. I would suggest however, that one of the aims of this article is to contribute constructively to discussion about opening up more space for the diversity of Maori, and for Maori economic activities.

\section{Diverse Economies}

In the second part of this article, I propose that the work of feminist Marxists Julie Graham and Katherine Gibson (J.K. Gibson-Graham) can provide some useful ways of thinking differently and produce a more complex picture, in this case, of Tuaropaki Power Company.

The work of Gibson-Graham has emerged and become influential alongside others, particularly in economic geography, who are seeking to explain and acknowledge "hidden economies" (Cameron 2008) and the "hybrid economy" (Altman 2004). Cameron argues that the hidden economy makes a significant contribution to our societies. In member countries of the Organization for Economic Cooperation and Development (OECD), she argues that research has shown that roughly the same amount of time is spent doing unpaid household work as is spent doing paid work. When monetary value is placed on this work, Cameron argues, the value of goods and services produced in households by unpaid workers is about the same as the value of goods and services produced by paid workers for the markets. The value of the hidden economy is more than just what can be viewed in monetary terms however, and Cameron points to "social and community relationships" $(2008,2)$ that are intertwined in the hidden economy. Cameron's work is crucial for the argument in this paper as it highlights that economies never consist simply of paid workers, working in enterprises in a capitalist economy. For Indigenous peoples, the notion of hidden economies is critical as much voluntary activity, for example, often goes unnoticed by many economists. In addition, the issue of intertwined activities of diverse economies building communities is helpful when thinking about Indigenous diverse economies. Maori economic activities begin from unique places and create unique institutions, as I will explore in the example below.

J.C. Altman (2004) argues that Indigenous economic development in Australia needs to be examined in the framework of an "indigenous hybrid economy." A hybrid economy, he argues, describes "communities with customary (or Aboriginal) market (or private) and state (public) sectors" (521). Altman argues that economists have 
failed to correctly conceptuali[z]e remote indigenous economies by ignoring non-market activities and the connections between such activities and state and the market sectors of the economy...there has been insufficient recognition of many social benefits that are generated by the hybrid economy and consequently an inability to recogni[z]e its potential to generate more social benefits if more realistically resourced (521).

While Altman's work intersects with the literature on hybridity, which originated in post-colonial theory (Bhabha 1994), he suggests that he is not using it in the same theoretical way but rather with reference to "public policy discourse" (see Russell 2011, 2). ${ }^{2}$

Altman's framework of a hybrid Indigenous economy supports the idea of considering Indigenous economies in different ways including the places where overlap or hybridity is evident, and connects with the arguments presented by Gibson-Graham of seeking a more detailed picture and language of economies.

Gibson-Graham have written extensively about community economies and alternative economies. Their general argument is that, instead of focussing on what is not going well in the world, academics need to focus on what is working successfully $(1996 ; 2006 ; 2009)$. As part of their argument for new ways of speaking about economies and "doing" thinking, Gibson-Graham emphasize the existence of extensive diverse economies. Through their work in communities, Gibson-Graham have formulated the image of an iceberg to provide a picture of the diverse economy (see Figure 1). The iceberg shows how some parts of the economy are visible, but that most forms of transactions, production, and enterprises are hidden $(2009,328)$. Gibson-Graham also argue that a focus on diverse economies highlights the diversity of transactions, labour, and forms of enterprise (2006, 60). Excavating the kinds of hidden activities and enterprises as they relate to Maori presents the opportunity to uncover previously marginalised activities or to re-examine those activities that have been understood as simply "traditional," but are instead a mix.

The second element to Gibson-Graham's theorizing is to deploy different theoretical tactics. Gibson-Graham propose the use of "weak theory," the goal of which, they argue, is not to confirm what we already know but, rather, to "help us see openings to help us to find happiness, to provide a space of freedom and possibility" $(2006,7)$. Weak theory, they suggest, reduces certainty and makes room for Others. Weak theory is "little better than description" (71), and

proliferates difference in the economic landscape and at the same time calls into question the hegemonic capitalocentric dynamics-mechanistic logics of reproduction, growth, accumulation, commodification, concentration, and centralization-on which capitalism's naturalness (and naturalized dominance) are grounded (71).

Utilizing weak theory might assist in de-linking theorizing about Maori economic activities from a critical and resistance stance, which is more dismissive of new possibilities (Gibson-Graham 2009, 324), and instead foster more hopeful notions of Maori as full of potential. 
The weak theory Gibson-Graham suggest encourages the exploration of the "exercise of diverse forms of power" (2006, 71-72). For examining Maori enterprises, this is vitally important so that they are not simply conceived as "without" power or as just capitalist entities but, rather, as enacting various forms of power. This re-focus has the potential to re-imagine Maori in new ways that do not reinforce binaries of Maori resistance to colonization.

The final aspect of the Gibson-Graham framework that I propose may be useful is being place- and time-specific when theorizing. Gibson-Graham describe this as focusing on the "now and here" (2006, xxi). I prefer to articulate this as "place and time specific," which allows for the significance and importance of the Maori adage nga wa o mua ("the days gone before us"), but doesn't necessarily produce the paralysis from the existence of the past (which is what Gibson-Graham warn against). It also caters to Gibson-Graham's description of weak theory as not presuming that "relationships between distinct sites of the diverse economy are structured in predictable ways, but observes the ways they are always differently produced according to specific geographies, histories, and ethical practices" $(2006,71)$.

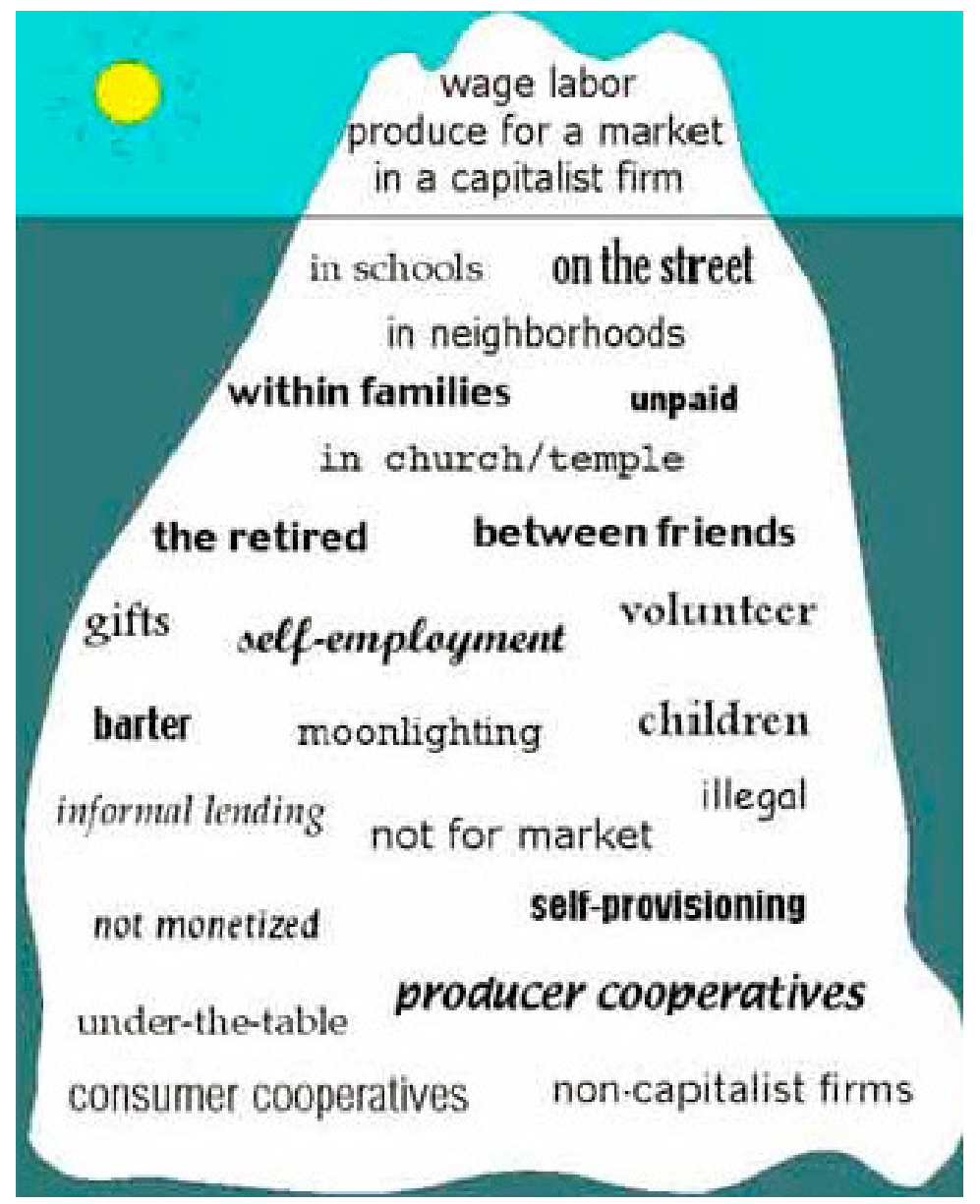

Fig. 1. The Visible and Hidden Parts of the Economy (The Iceberg) ${ }^{3}$ 


\section{A Case Study: Tuaropaki Power Company}

How does this framework look in the case of a Maori geothermal power company? I have been inspired to focus on Tuaropaki Power Company because of genealogical links and knowledge shared between my own hapu Ngati Kea/Ngati Tuara and people from Mokai. Like the hapu of Mokai, Ngati Kea/Ngati Tuara have geothermal resources under our lands at Horohoro, Rotorua. As Tuaropaki have become a well-known example, they have generously contributed their time to many projects (TPK, FOMA 2005) but are now at a point where a great deal of information about them is provided on their website (Tuarpoaki.com). When I approached them, they indicated that they now have a policy of directing interested people to their website and other published resources as the best sources of information and the best use of their time. Respectful of the fact that an academic article may not be something they feel they need to have direct input into, I analysed the material they suggested. Consequently, the focus here is on literature, rather than interviews.

To provide an example of the complexity when examining a Maori corporation "up close," as in this case, I have placed the Tuaropaki Power Company into an extended version of a grid created by Gibson-Graham (2006). I have added the category of "property and resource ownership" because, in the case of Maori, the relationships with the land and other resources continue to hold particular significance to relations of production and transactions (Durie 1998).

The grid shows how the Tuaropaki Power Company can be understood in far more complex, and potentially optimistic terms, rather than simplistically as a capitalist corporate entity. As mentioned above, rather than using interviews for the information here, I have used publicly available information about the Tuaropaki Trust or information that they have published themselves to begin to show how this information can be configured in new ways. Instead of considering the Tuaropaki Power Company as simply one type of enterprise, or as conducting one type of business, and highlighting the multiple dimensions of the enterprise, looking at transactions, labour, and resource and property ownership gives a broader picture of the economies involved.

Tuaropaki Power Company is based at Mokai, in the central North Island of Aotearoa, New Zealand. It was established in 1994 by the Tuaropaki Trust. Tuaropaki Power Company obtained resource consents for geothermal development in 1994 (Tuaropaki Trust 2005b, $10)$. A geothermal power station was completed by 2000 . A second plant was completed in 2005, and both plants combined are able to supply power for approximately 100,000 homes, which then is sold into the national grid. Tuaropaki Power Company was 100 percent owned by the Trust until 2003, when a quarter share was acquired by its business partner, a State-Owned Enterprise, Mighty River Power (Tuaropaki Trust 2005a, 4). Tuaropaki Power Company board is governed by four people, three from Tuaropaki and one from Mighty River Power (Tuaropaki Trust 2005a, 10).

The Tuaropaki Trust is an amalgamation of multiple-owned lands that can be traced to the descendents of seven Mokai hapu: Ngati Parekaawa, Ngati Kohera, Ngati Wairangi, Ngati Whaita, Ngati Moekino, Ngati Haa, and Ngati Tarakaiahi (Te Puni Kokiri and Federation of Māori Authorities 2005). In 1951, owners of the forty-three land blocks surrounding Mokai amalgamated to develop a single pastoral farm. Finance received from the Department of Māori Affairs was conditional upon the department managing the farm 
until the loan was repaid. In 1979, the loan and interest was repaid and the Department of Māori Affairs returned the land back to its owners, with the Māori Land Court appointing the initial trustees (Tuaropaki Trust, 2005a). In 1982-83, the New Zealand government began exploration of the geothermal fields, drilling investigatory wells on Tuaropaki lands. Proposals to build electricity power plants had not been discussed with the Trust, and it became apparent the government intended to sideline Tuaropaki (Tuaropaki Trust 2005a). The Trust decided to carry out the development itself (Tuaropaki Trust 2005a), and in 1994, the Māori Land Court confirmed that Tuaropaki owned all government wells and fixtures on Tuaropaki lands.

The Tuaropaki Trust argues that the decrease in global oil and gas reserves and the increasing demand for renewable energy places them in a unique position to provide geothermal energy for electricity (Tuaropaki Trust 2005b). They acknowledge, however, that the loss of energy in the conversion of electricity means it is not the most efficient way of using the energy. It is more efficient, they argue to "use geothermal energy to provide heat direct to those enterprises that require substantial amounts of heat energy. The challenge is to locate such enterprises and encourage them to establish on, or in close proximity to, Tuaropaki land" (Tuaropaki Trust 2005b, 9). The construction of a milk factory (Miraka) on Tuaropaki land is an attempt to draw large consumers of energy geographically closer to them (Wairarapa Moana 2010).

In the grid below, I have plotted some elements of the Tuaropaki Power Company (See Figure 2).

\section{Enterprise}

In terms of the enterprise itself, the Tuaropaki Power Company is owned (as per the Maori Land Act 1993) by a Maori Land Trust called Tuaropaki Ahu Whenua Trust, the overall aim of which is to provide "a beacon of hope" (Tuaropaki 2005a) for their people. The company is, at a fundamental level, based on supporting relationships amongst people, specifically for the descendants of the seven Mokai hapu, and promoting their wellbeing. The fundamental relationships between people who are related to one another (in this instance, members of the seven Mokai hapu), provides the central rationale for the establishment of the enterprise, as well as how and where it is located, and what the aim of the company is.

\section{Transactions and Labour}

The company has a sustainability focus, not only in looking after the land and surrounding environment by engaging in renewable energy, but also for the livelihoods of Mokai people by encouraging participation and job opportunities with the company and Trust. When the power station was first built it generated little employment, so Tuaropaki subsequently built greenhouses on that land to serve the dual functions of creating employment and utilizing the geothermal power. The wage labour of the company sits alongside unpaid activities of its directors-particularly those activities that support their marae (carved meeting house) or other Maori businesses. A worm farm has also been created to consume literally the waste created by the greenhouses, reaffirming a focus on environmental protection (Wairarapa Moana 2010) and reciprocity between people and the environment. 


\begin{tabular}{|c|c|c|c|}
\hline Transactions & Labour & Enterprise & $\begin{array}{l}\text { Property and Resource } \\
\text { Ownership }\end{array}$ \\
\hline $\begin{array}{l}\text { Market } \\
\text { Power sold to national } \\
\text { grid. } \\
\text { As per joint venture, } \\
\text { Mighty River Power } \\
\text { provides long-term } \\
\text { support for the sale of } \\
\text { electricity. }\end{array}$ & $\begin{array}{l}\text { Wage } \\
\text { Salary } \\
\text { As per joint venture, } \\
\text { Mighty River Power } \\
\text { conduct maintenance of } \\
\text { steamfield, power-plant, } \\
\text { and transmission systems } \\
\text { and marketing. } \\
\text { Contracting of Strettons } \\
\text { Chartered Accountants to } \\
\text { manage enquiries and } \\
\text { accounts. }\end{array}$ & $\begin{array}{l}\text { Capitalist } \\
\text { Board of Directors ( } 3 \text { from } \\
\text { Tuaropaki Trust and } 1 \\
\text { representative of the joint } \\
\text { venture). } \\
\text { Dividends paid to shareholders. }\end{array}$ & $\begin{array}{l}\text { Capitalist } \\
\text { As per joint venture, } 1 / 4 \text { of Mokai } \\
\text { II is owned by Mighty River } \\
\text { Power. }\end{array}$ \\
\hline $\begin{array}{l}\text { Alternative Market } \\
\text { Koha (including for } \\
\text { corporate gifts to trading } \\
\text { partners) }\end{array}$ & $\begin{array}{l}\text { Alternative Paid } \\
\text { In-kind. } \\
\text { Long term pay off-Meeting } \\
\text { with key stakeholders. } \\
\text { Environmental- } \\
\text { replenishing of water in } \\
\text { geothermal area beneath } \\
\text { power plant. }\end{array}$ & $\begin{array}{l}\text { Alternative Capitalist } \\
\text { Scholarships for education and } \\
\text { kaumatua grants (aim is for } \\
\text { equitable distribution). }\end{array}$ & $\begin{array}{l}\text { Alternative Capitalist } \\
\text { Right to extract granted to } \\
\text { Tuaropaki Power Co. because of } \\
\text { whanau link to Tuaropaki Trust. } \\
\text { Land (Tuaropaki E block) owned } \\
\text { by Tuaropaki Trust. Approx. } 30 \\
\text { hectares for steamfield wells, } \\
\text { pipelines, and electricity } \\
\text { generating plant. }\end{array}$ \\
\hline $\begin{array}{l}\text { Non-market } \\
\text { State allocations. } \\
\text { State appropriations = } \\
\text { corporate tax, local } \\
\text { government rates? } \\
\text { Whanaungatanga (care for } \\
\text { family). } \\
\text { Kaitiakitanga } \\
\text { (guardianship). Potentially } \\
\text { the sustainability focus } \\
\text { and activities of the } \\
\text { company could be } \\
\text { understood as } \\
\text { transactions with } \\
\text { Papatuanuku (Mother } \\
\text { Earth) - replenishing. }\end{array}$ & $\begin{array}{l}\text { Unpaid } \\
\text { Presentations made at } \\
\text { conference by Directors } \\
\text { and Chairperson. } \\
\text { Attendance at various } \\
\text { marae meetings by } \\
\text { Directors and Chairperson } \\
\text { which they connect to. } \\
\text { Advice to other Maori } \\
\text { businesses. }\end{array}$ & $\begin{array}{l}\text { Non-capitalist } \\
\text { Tuaropaki Trust comprised of } 7 \\
\text { Mokai hapu. The Trust is an } \\
\text { Ahu Whenua Trust, managing } \\
\text { Maori freehold land under Te } \\
\text { Ture Whenua Maori Act } 1993 . \\
\text { Tuaropaki Power Co. is wholly } \\
\text { owned by Tuaropaki Trust. } \\
\text { Maori Land Court appoints } \\
\text { trustees to Tuaropkai Trust and } \\
\text { holds Trust Order/Deed } \\
\text { (provides legal framework) and } \\
\text { requires the Trust administer } \\
\text { "the lands for the benefit of the } \\
\text { beneficial owners" (Tuaropaki). } \\
\text { Tuaropaki Trust maintenance } \\
\text { of Marae community complex. }\end{array}$ & $\begin{array}{l}\text { Non-capitalist } \\
\text { State-resource consents from } \\
\text { Environment Waikato (the } \\
\text { regional council). } \\
\text { Whakapapa (geneology) - } \\
\text { descendants of the hapu } \\
\text { involved have genealogical and } \\
\text { spiritual ties to each other and } \\
\text { the lands involved. }\end{array}$ \\
\hline
\end{tabular}

Fig. 2. The Diverse Economy of Tuaropaki Power Company Ltd 


\section{Property and Resource Ownership}

The infrastructure of the power plant itself is owned as part of the joint venture with Mighty River Power; however, the land is owned by the Tuaropaki Trust as a form of Maori land under the Maori Land Act 1993. Arguably, it also belongs more broadly to those who have whakapapa (have genealogical ties) to all those sub-tribes involved. There are therefore a mix of connections to the land and resources.

\section{Conclusion}

Let me return to the concerns which initiated this investigation. Different critiques, in this case of Maori economic activities, create different institutional politics. Claims that the success of particular forms of Maori entrepreneurialism provides evidence of the triumph of the "modern"/Western over the "traditional" suggest that using particular types of institutions are the only way to become more Western. And, yet, by examining Maori economic activities with a wider lens such as that provided by Gibson-Graham, a more populated economic terrain becomes visible. The notion that particular institutions are singular types and more or less advanced along a continuum than others appears problematic. In a sense, however, neither Maori entrepreneurs nor advocates of diverse economies need to argue that they have triumphed.

A diverse economy approach demonstrates that companies, Maori or otherwise, are not simplistically capitalist or non-capitalist but contain multiple forms of transactions, labour, resource, and property ownership. They are part of a complex array of intersecting and diverging co-ordinates. Using a diverse economies approach and deploying different theoretical tactics allows for a more complex and richer picture of what is taking place. In amongst this diverse economy, therefore, Maori energy production activities may be seen not as evidence of the superiority of, say, capitalist agendas, but perhaps as diverse ways in which Maori are being powerful.

\section{Endnotes}

1. I define Maori economies as those which involve Maori people and which often involve Maori land and other natural resources (Durie 1998).

2. Due to space constraints I am not able to elaborate further on the connection between Altman's work and post-colonial theory. However, Susie Russell has provided a detailed exploration in her work that I refer the reader to (2011).

3. Available from the Community Economies Collective website, http://www. communityeconomies.org 


\section{Bibliography}

Altman, J. C. 2004. "Economic development and Indigenous Australia: contestations over property, institutions and ideology." Australian Journal of Agricultural and Resource Economics 48 (3): 513-34. http://dx.doi.org/10.1111/j.14678489.2004.00253.x

Anderson R. B., L. P. Dana, and T. Dana. 2006. "Indigenous land rights, entrepreneurship, and economic development in Canada: 'Opting-in' to the global economy," Journal of World Business 41 (1): 45-55. http://dx.doi.org/10.1016/j.jwb.2005.10.005

Ashcroft, B., G. Griffiths, and H. Tiffin. 1989. The Empire Writes Back. London: Routledge.

Bargh, M. 2002. Re-colonization and Indigenous Resistance: Neoliberalism in the Pacific. PhD diss., Australian National University. https:/digitalcollections.anu.edu.au/ handle/1885/7368.

_-_- - 2007. Resistance: An Indigenous Response to Neoliberalism. Wellington: Huia Publishers.

Bannock, G., R.E. Baxter, and E. Davis. 1998. The Penguin Dictionary of Economics. London: Penguin.

Bhabha, H. K. The Location of Culture. London: Routledge.

Cameron, J. 2008. "The Contribution of Community Enterprises to the Development of Regions." Presentation to the Australian Regional Economy Conference Terrigal, NSW.

Cameron J., and K. Gibson. 2008. "ABCD Meets DEF: Using Asset Based Community Development to Build Economic Diversity." Paper presented at the Asset Based Community Development conference, University of Newcastle, 3-5 December. http://www.communityeconomies.org/site/assets/media/old\%20website\%20 pdfs/Papers/On\%20community\%20economies/ABCD\%20Meets\%20DEF\%20 Using\%20Asset\%20Based\%20Community\%20Development\%20to\%20Build\%20 Economic\%20Diversity.pdf.

Cram, F. 2001. "Rangahau Maori: Tona Tika, Tona Pono." In Research Ethics in Aotearoa, ed. M. Tolich, 45-52. Auckland: Longman.

Dana, L.P and R. B. Anderson. 2007. International Handbook of Research on Indigenous Entrepreneurship. Cheltenham, UK: Edward Elgar.

Durie, M. 1998. Te Mana, Te Kawanatanga: The Politics of Māori Self-Determination. Auckland, NZ: Oxford University Press.

Eketone, A. 2008. “Theoretical underpinnings of Kaupapa Māori directed practice.” MAI Review 1, 1-11. http://www.review.mai.ac.nz/index.php/MR/article/view/98/106

Escobar, A. 1997. "The Making and Unmaking of the Third World through Development." In The Post-Development Reader, ed. M. Rahnema and V. Bawtree, 85-93. London: Zed Books. 
Gibson-Graham, J.K. 1996. The End of Capitalism as We Knew It. Oxford: Blackwell.

- - - - 2006. A Postcapitalist Politics. Minneapolis: University of Minnesota Press.

_-__—. 2009. "An Economic Ethics for the Anthropocene." Antipode 41 (1): 320-46.

Henry, E. 2007. “Kaupapa Maori Entrepreneurship." In International Handbook of Research on Indigenous Entrepreneurship, ed. L. P. Dana, and R. B. Anderson, 53648. Cheltenham, UK: Edward Elgar.

Hindess, B. 2001. “The Liberal Government of Unfreedom.” Alternatives 26 (2): 93-111.

_—_— . 2007. “The Past is Another Culture.” International Political Sociology 1 (4): 325-38.

_-__—. 2010. "Time and the Others." A paper presented at the Oceanic Conference on International Studies, Auckland University, July.

Hokowhitu, B. 2010. “A Genealogy of Indigenous Resistance.” In Indigenous Identity and Resistance: Researching the Diversity of Knowledge, ed. B. Hokowhitu, N. Kermoal, C. Andersen, A. Petersen, M. Reilly, I. Altamirano-Jimenez, and P. Rewi, 207-25. Dunedin, NZ: University of Otago Press.

Hutchings, J. 2002. Te Whakaruruhau, Te Ukaipo: Mana Wahine and Genetic Modification. PhD diss., Victoria University of Wellington.

Irwin, K. 1994. "Maori Research Methods and Processes: An Exploration." Sites 28: 25-43.

Keelan. J. and C. R. Woods. 2006. "Mauipreneur: understanding Maori entrepreneurship." International Indigenous Journal of Entrepreneurship, Advancement, Strategy and Education 2 (2): 1-20. http://www.Indigenousjournal.com/read.html.

Kennedy, V. and F. Cram. 2010. "Ethics of researching with Whanau Collectives." MAI Review 3: 1-8. http://www.review.mai.ac.nz/index.php/MR/article/view/381/560

LaDuke, W. 2005. Recovering the Sacred. Cambridge, MA: South End Press.

Lewis, N., O. Lewis, and Y. Underhill-Sem. 2009. "Filling the Hollowed Out Spaces with Localised Meanings, Practices and Hope: Progressive Neoliberal Spaces in Te Rarawa." Asia Pacific Viewpoint 50 (2): 166-84. http://dx.doi.org/10.1111/j.14678373.2009.01391.x

Maaka, R., and A. Fleras. 2005. The Politics of Indigeneity. Otago: Otago University Press.

Mahuika, R. 2008. “Kaupapa Māori theory is critical and anti-colonial.” MAI Review 3: 1-16 http://www.review.mai.ac.nz/index.php/MR/article/viewFile/153/180.

O’Sullivan, J., and T. Dana. 2008. "Redefining Maori economic development." International Journal of Social Economics 35 (5): 364-79.

Pihama, L. 2001. Tihei maurior:, Honouring our voices. Manawahine as a Kaupapa Maori Theoretical Framework. PhD diss., The University of Auckland.

Pihama, L., and M. Penehira. 2005. Building Baseline Data On Maori, Whanau Development And Maori Realizing Their Potential: Literature Review: Innovation And Enterprise. Auckland: International Research Institute for Maori and Indigenous Education. 
Rata, E. 2000. A Political Economy of Neotribal Capitalism. Lanham, MD and Oxford: Lexington Books.

Reed, A. W. 2004. Reed Book of Maori Mythology. Auckland: Reed Publishing.

Russell, S. 2011. “The Hybrid Economy Topic Guide.” Canberra: Centre for Aboriginal Economic Policy and Research. www.caepr.anu.edu.au.

Said, E. 1978. Orientalism. New York: Vintage Books.

Samuelson P. A., and W.D. Nordhaus. 1995. Economics: Fifteenth Edition. Boston: McGraw-Hill.

Sautet, F. 2008. "Once Were Iwi? A Brief Institutional Analysis of Maori Tribal Organizations Through Time.” Working Paper 3. Wellington, NZ: New Zealand Business Roundtable.

Shane, S. A. 2003. A General Theory of Entrepreneurship: The Individual Opportunity Nexus. Northampton, MA: Edward Elgar Publishing.

Shiva, V. 2000. "Foreword: Cultural Diversity and the Politics of Knowledge." In Indigenous Knowledges in Global Contexts, ed. G. J. Sefa Dei, B. L. Hall, and D. G. Rosenberg, vii-x. Toronto: University of Toronto Press.

Smith, C. 2007. "Cultures of Collecting." In Resistance: An Indigenous Response to Neoiberalism, ed. M. Bargh, 65-74. Wellington, NZ: Huia Publishers.

Smith, L. 1999 Decolonizing Methodologies. London: Zed Books.

Tapsell, P. and C. Woods. "Potikitanga: Indigenous Entrepreneurship in a Maori Context." Journal of Enterprizing Communities 2 (3): 192-203.

Te Puni Kokiri. 2007. For Maori Future Makers: Nga Kaihanga Hou. Wellington, NZ: Te Puni Kokiri.

Te Puni Kokiri and the Federation of Maori Authorities. 2005. Maori Business Innovation and Venture Partnerships: Hei Whakatinana I te Turua Po. Wellington, NZ: Ministry of Maori Development and Federation of Maori Authorities.

Te Punga Somerville, A. 2011. "Neither Qualitative nor Quantitative: Kaupapa Maori Methodology, and the Humanities." paper presented at the Kei Tua o Te Pae conference, Wellington, New Zealand, May.

Tuaropaki Trust. Official website. www.Tuaropaki.com.

-__—_. 2005a. Tuaropaki Information Pamphlet.

_-__—. 2005b. Tuaropaki Annual Report 2005. Mokai: Tuaropaki Trust.

Wairarapa Moana Incorporation. 2010. Wairarapa Moana Mailer, September.

Whitehead J. and B. Annesle. 2005. The Context for Maori Economic Development Wellington: NZ Treasury. 
Warriner, V.C.A. 2009. "Internationalization of Maori Businesses in the Creative Industry Sector: Ko te rerenga o te toki a Tù, he whare oranga." PhD diss., Massey University, Albany, New Zealand.

Young, R.J. 2001. Postcolonialism: An Introduction. London: Blackwell. 